\title{
The using of arthroscopy and synovial biopsy in chronic knee monoarthritis in children
}

\section{IA Chicova, VV Avramenko and MM Kostik*}

Address: State Pediatric Medical Academy, Saint-Petersburg, Russian Federation

* Corresponding author

from $15^{\text {th }}$ Paediatric Rheumatology European Society (PreS) Congress

London, UK. 14-17 September 2008

Published: 15 September 2008

Pediatric Rheumatology 2008, 6(SuppI I):P82 doi:I0.I I86/I546-0096-6-SI-P82

This abstract is available from: http://www.ped-rheum.com/content/6/SI/P82

(c) 2008 Chicova et al; licensee BioMed Central Ltd.

The knee damage in children may be a sign of many diseases. They include bone and joint infections, neoplastic disorders, trauma and arthritis.

The aim of our study was to detect diseases which coursing with knee damage and to reveal arthroscopic and synovial histological changes.

We included in our study 29 children with chronic knee monoarthritis (CKMA), 15 girls and 14 boys with duration knee monoarthritis symptoms $>6$ weeks. Most of the patients were examined with arthrosonography and MRI. Arthroscopy with synovial biopsy was performed on 10 children ( 2 with tuberculosis infection and 8 with CKMA unknown origin).

Five CKMA boys transformed in juvenile spondiloarthropathy (3 had psoriatic arthritis). Juvenile rheumatoid arthritis was diagnosed in 6 children ( $4 \mathrm{~F}: 2 \mathrm{M}$ ), all girls were ANA-positive and developed oligoarthritis and one also had uveitis. There were 3 cases of tuberculosis arthritis without primary lung damage. Another cases included knee osteoarthritis, Borrellia burgdorfery infection, angiodysplasia of knee, posttraumatic arthritis with meniscus damage, osteochondritis dissecans and Hoffa disease. The largest group consisted of children with chronic villous proliferate synovitis (6 F: $2 \mathrm{M}$ ) unknown origin was revealed by arthroscopy and synovial biopsy. Chlamydia infection was detected in synovial fluid and membrane in 2 children.
Synovial histology was determined as focal hypertrophy of synovial membrane with mononuclear cell infiltration in half patients as signs of neoangiogenesis in another part. This form of CKMA was torpid.

CKMA is very geterogenous; some of them need in arthroscopy with synovial biopsy. 